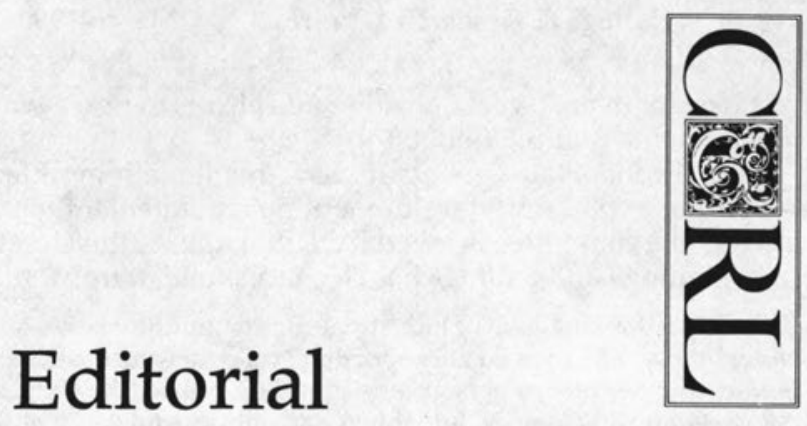

\title{
Collection Development: The JANUS Image
}

In this issue there are several articles on various aspects of collection development. This is a good sign-especially for me, because I am fascinated by the subject. Collection development seems to have an ideal blend of the scholarly and the practical. One can roam from building collections to selecting a title. One can review world publishing trends or talk with a faculty member about research interests. New academic disciplines or subfields, conservation, materials budgets, book use patterns, purchasing power, and form of material are but a few of the issues that the collection development librarians must deal with on a regular basis.

The implicit blend of art and science has a subtle allure. However, I tend to waver between the creative or intuitive aspects and the objective factors. For example, I often pose questions, review what I know, and arrive at tentative conclusions. One day I estimated that the ARL libraries collectively spend between $\$ 200,000,000$ and $\$ 500,000,000$ annually on books and other media. Next I asked myself a series of questions: (1) how well do the ARL libraries collectively spend their book funds, (2) how well do individual libraries spend their book funds, and (3) how well do individual selectors spend their book funds?

The difficulty of answering any of these questions is obvious to those who have tried even simple collection assessments. They take a great deal of time to do, and the results are often sketchy.

"Collection Description and Assessment in ARL Libraries," SPEC Kit \#87 by ARL/OMS (Sept. 1982), is an excellent compilation of noteworthy activity at both small and large academic libraries. As usual in the SPEC Kit Series, the introduction is succinct and insightful: "The renewed emphasis on assessment has led to a greater understanding of the issues involved in the book fund allocation process and has contributed to the development of a better trained and more knowledgeable corps of bibliographers and selectors."

Given the magnitude of our annual expenditures on books, it is fortunate that our understanding of the book fund allocation process is increasing. What we still need to find is a library wunderkind who can develop a simple, easy-to-apply technique by which the quality of collections and the quality of selection decisions can be regularly assessed.

The unknowns in current practice loom large. The difficulty in coming to reasonable conclusions based on objective studies should not deter us but should prod us on. How many of you remember the perplexed, almost confused response of some collection development librarians in the late 1970 s, when inflation, wild foreign currency fluctuations, and a downturn in economic growth caused projections of annual serials costs to run out of control? At one major university library, actual serials costs ran between 30 and 40 percent over budgeted figures. Roger Presley and others (Academic Libraries: Myths \& Realities, Proceeding of the Third National Conference of the Association of College and Research Libraries) characterized the 1980-82 period as "devastating" for materials budgets. Forty-four percent of the libraries responding to the Presley survey "had to stop ordering new or added periodical subscriptions." A majority of libraries had to cancel titles. For Jasper Schad, "apportioning materials budgets is a collection development problem and the failure to grasp that 
fact has, for over 70 years, misdirected efforts to find a workable solution." [Journal of Academic Librarianship 3:6 (Jan. 1978)]

At California State University, Sacramento, a committee chaired by Barbara Charlton is preparing a collection-development policy statement to guide library activity in the years ahead. The committee is called JANUS. JANUS, the Greek guardian of portals and patron of beginnings and endings has two faces, one in front, the other at the back of his head.

In Janusian thinking, two or more opposites or antitheses are conceived simultaneously, either as existing side by side, or as equally operative, valid, or true. In an apparent defiance of logic or of physical possibility, the creative person consciously formulates the simultaneous operation of antithetical elements and develops those into integrated entities and creation. It is a leap that transcends ordinary logic. (William R. Scott, Organizations: Rational, Natural, and Open Systems, p. 55)

Collection development librarians require a similar talent. The complexity, contradictions, and internal tensions of collection building offer little hope of easy solutions. The logic of the science is confounded daily by the practical and often political context in which libraries operate. The skill with which collection development librarians resolve these contradictions will affect us all-staff and user. Continuing research in this critical area should be encouraged vigorously. College $\&$ Research Libraries joins with others to welcome this concentrated attention. A likely result is that libraries and librarians will be able to use their resources more effectively.

\section{CHARLES MARTELL}

\section{IN FORTHCOMING ISSUES OF COLLEGE \& RESEARCH LIBRARIES}

1985-1995: The Next Decade in Academic Librarianship by Allen B. Veaner

Measuring Levels of Work in Academic Libraries-A Time Based Approach by Donald P. Gould

The Decision-Making Process Involved in Applying Computer Technology to Library Operations

by $\mathrm{R}$. Wilburn Clouse and Birdie O. Weir

Theories of Innovation and Applications to Libraries

by Judy Reynolds and Jo Bell Whitlach

Production of Scholarly Articles by Academic Librarians and Library School Faculty by Paula D. Watson

Publication Requirements and Tenure Approval Rates: An Issue for Academic Librarians by W. Bede Mitchell and L. Stanislava Swieszkowski 